\title{
Olga NADSKAKUŁA
}

Uniwersytet Łódzki

\section{Zachód jako punkt odniesienia rosyjskiej polityki zagranicznej}

\begin{abstract}
„W oczach Rosjan Zachód dobrze prosperuje, jest wspaniale zorganizowany, inteligentny i sprawny, ale jednocześnie sztuczny, zimny, wyrachowany, zamknięty w sobie, niezdolny do wielkich czynów i prawdziwych emocji"'.
\end{abstract}

$\mathrm{Z}$ achód jest jednym z najważniejszych kryteriów odwoławczych rosyjskiej myśli politycznej, historycznej czy ideologicznej. Dzieje się tak dlatego, ponieważ tożsamość rosyjska kształtowana jest przede wszystkim na płaszczyźnie porównawczej z Zachodem. Jak długo więc Rosja zastanawiać się będzie nad samą sobą, tak długo miernikiem tego „określania” się będzie stosunek do Zachodu. W różnych okresach historycznych relacja ta przybierała odmienny charakter, zawsze jednak oscylowała między skrajnym zachwytem nad zachodnią cywilizacją i skrajną dezaprobatą jej osiagnięć.

Definiując oba stanowiska, zacząć musimy od geograficznego wymiaru pojęcia ZACHÓD. Do Zachodu, w rosyjskim rozumieniu, należą kraje europejskie kultury Romano-Germańskiej, kraje anglosaskie, a także Stany Zjednoczone, Australia i Nowa Zelandia. Stanowią one, zdaniem rosyjskich myślicieli, cywilizacyjną jednię, charakteryzującą się wysokim stopniem modernizacji, określonym modelem rozwoju politycznego opierającym się na wartościach liberalnych i szczególnych zasadach życia społecznego. To właśnie ocena zachodniej drogi rozwojowej ukształtowała dwie postawy w rosyjskim myśleniu o Zachodzie. Podział na wrogów i sympatyków Zachodu sięga czasów Piotra I, a w XIX wieku obrazuje go oficjalny spór między słowianofilami i okcydentalistami. „Cały wiek XIX zaznaczony był pęknięciem i walką dwóch tendencji. Jedna z nich postulowała odrzucenie kultury zachodniej i powrót do staro-

1 D. Remnick, Zmartwychwsanie, Warszawa 1997, s. 114. 
ruskiej jedności kulturowej, widząc w tradycyjnych formach społecznych dawnej Rusi nadzieję na przyszłe odrodzenie społeczeństwa rosyjskiego. Druga była natomiast intencjonalnie propozycją konsekwentnej okcydentalizacji, objęcia procesami europeizacyjnymi całego społeczeństwa"2. Podział na tych, którzy z Zachodem wiążą tylko zimny racjonalizm, społeczną atomizację i barbarzyńską cywilizację mieszczańską i tych, którzy postulują asymilację zachodnich wartości, ma swoje kontynuacje w wieku XX i XXI. Bez historycznych odwołań nie sposób więc zrozumieć dzisiejszej polityki zagranicznej Rosji.

Pierwsza poważna styczność Rosji z kulturą zachodnią miała miejsce w czasie panowania Piotra I i związana była z przeprowadzeniem reform na modłę „zachodnią” oraz próbą recepcji europejskich wartości. To właśnie Europa Zachodnia stanowiła dla Piotra I standard modernizacji i wzorzec właściwej drogi rozwojowej. Etos „europejski” zostaje przez cara określony jako dziedzictwo wysublimowanej kultury, i w tym sensie „europejski” oznaczało tyle co „kulturalny” czy „,cywilizowany”3. Zasadniczym celem polityki Piotra I było więc umieszczenie Rosji w tym kręgu cywilizacyjnego ideału. Żyjący w XIX wieku rosyjski myśliciel Piotr Czaadajew określił działania cara w następujący sposób „Piotr Wielki znalazł w swoim domu tylko kartkę białego papieru i swą silną ręką napisał na niej słowa: Europa i Zachód, i od tej pory należymy do Europy i Zachodu" . Okres panowania Piotra I możemy śmiało uznać za początek „świadomej” polityki wobec Zachodu.

Mimo, iż to właśnie Piotr I wyrwał Rosję z „antymodernizacyjnego" letargu, jego dokonania nie były i nie są oceniane jednoznacznie pozytywnie przez potomnych. Ma to związek z negatywnymi konsekwencjami jego reform. Jak twierdzi Andrzej Anrdusiewicz w „Micie Rosji”, w owym czasie „w duszy rosyjskiej zapanował brak koordynacji wewnętrznej, rozbieżność szlachetnych zasad abstrakcyjnych i barbarzyńskich instynktów, kult nauki i zupełny względem niej sceptycyzm, przejęcie się hasłami postępu oświeconej Europy obok niechęci do samej cywilizacji europejskiej”, Krytyka „Piotrowych przekształceń” w znacznej mierze opiera się nie na odrzucaniu samego postępu, ale na sprzeciwie wobec naśladowania

2 M. Broda, Narodnickie ambiwalencje, Łódź 2003, s. 72.

3 Filozofia rosyjska wobec procesów modernizacyjnych, Kraków 1999, s. 105.

4 M. Broda, Narodnickie ambiwalencje, Łódź 2003, s. 48.

5 A. Andrusiewicz, Mit Rosji, Rzeszów 1994, s. 149. 
Zachodu przy jego wdrażaniu. Dla wielu bowiem myślicieli modernizacja była jednocześnie westernizacją, czyli dyfuzją zachodnich wartości połączoną z destrukcją rodzimej kultury. Problem ten był silnie podkreślany przez Mikołaja Trubeckiego (przedstawiciela idei euroazjatyzmu, o której później wspomnę). Jego zdaniem osobliwością kultury europejskiej jest egocentryzm, polegający na uznaniu własnych wartości za uniwersalne i ogólnoludzkie. Romano-Germanowie zaczęli zręcznie narzucać swój punkt widzenia innym kulturom. W Rosji europeizacyjna reforma przybiera postać zadekretowanej przez cara odgórnej rewolucji ustrojowej i kulturalnej, a w wieku XIX przechodzi w fazę poeuropeizacyjnego kry$z^{2} u^{6}$. Jest to bardzo jednostronna ocena, zwłaszcza, że nie obejmuje pozytywnych konsekwencji polityki cara, do których oprócz procesów modernizacyjnych należy też rozwój krytycznej myśli w Rosji.

Całościowe spojrzenie na epokę Piotra I pozwala nam poznać podstawę argumentacji przyszłych pro- lub antyzachodnich twórców rosyjskiej polityki zagranicznej.

Wiek XIX w Rosji to dalsza polaryzacja opcji światopoglądowych dotyczących Zachodu. Z korzeni idei słowianofilskiej i okcydentalistycznej wyrastały nowe koncepcje myślowe, dla wszystkich jednak bazą był stosunek do Zachodu. Nową treść i odmienną perspektywę do dyskusji wniósł w latach dwudziestych XX wieku Mikołaj Trubecki, twórca idei euroazjatyzmu. Jej podstawą było przekonanie o kulturowej, geopolitycznej i etnicznej odmienności Rosji od pozostałych kontynentów -Azji i Europy. „Kultura Rosji nie jest ani kulturą europejską, ani jedną z kultur azjatyckich [...]. Należy ją przeciwstawić kulturze Europy i Azji jako kulturę środka - kulturę euroazjatycką [...]. Wyzwoliwszy się z jarzma tatarskiego musimy także wyzwolić z siebie jarzmo europejskie"7. Mimo iż „Euroazjatyzm” miał wielu zwolenników w Rosji, nigdy nie stał się ideą organizującą życie obywateli i wyznaczającą priorytety polityki zagranicznej.

Taką wartość historyczną uzyskał natomiast rodzący się w tym samym czasie bolszewizm. Porewolucyjna sytuacja zmusiła bolszewików do określenia swego stanowiska wobec Zachodu. Przekonawszy się szybko, że wizja internacjonalistycznej rewolucji światowej okazała się mitem, przyjęli postawę antyokcydentalistyczną. Jej podstawą był jak pisze Alain Be-

6 Filozofia Rosyjska wobec problemów modernizacyjnych, Kraków 1999, s. 155.

7 E. Wyciszkiewicz, Współczesna Rosja wobec Zachodu, Łódź 2003, s. 25. 
sancon „wstręt do tego, co zewnętrzne wobec komunistycznego świata”8. W propagandzie radzieckiej centralnym przedmiotem krytyki staje się Ameryka utożsamiana $\mathrm{z}$ supermocarstwowym imperializmem, wyzyskiem mas pracujących, konsumpcyjną degradacją. W rezultacie ostrze radzieckiej polityki zagranicznej wymierzone było w Zachód. Oficjalną antyamerykańską ideologię wspierały także radzieckie media i sztuka. Oznacza to, że wrogość do Zachodu przenikała do świadomości obywateli ze wszystkich możliwych stron.

W 1985 roku w Związku Radzieckim wizja Zachodu zostaje zmodyfikowana. Nowa polityka przywódcy państwa i partii komunistycznej Michaiła Gorbaczowa stępiła ostrze antyzachodniej ideologii. „Pierestrojka” to okres przełamywania fałszywych schematów pojęciowych i stereotypów, w których Ameryka funkcjonuje jako „cywilizacja zdeprawowanej pop-mass kultury". Co więcej państwa zachodnie stały się niejako wzorem modernizacyjnych przekształceń w Związku Radzieckim.

Upadek imperium uaktualnił pytania o przyszłość Rosji i wybór nowej drogi. Po przegranej w ,zimnej wojnie” wszystkie spory dotyczące przeszłości, teraźniejszości i przyszłości Rosji nie wychodziły poza ramy alternatywy „kontynuacja, czy przezwyciężenie wrogości wobec Zachodu”.

Borys Jelcyn otworzył Rosję na Zachód, widząc w takiej polityce jedyny ratunek dla stojącego na rozdrożu, pozbawionego dotychczasowych, „radzieckich wartości” państwa. Konieczność przyjęcia prozachodniego punktu widzenia podkreślał były minister spraw zagranicznych - Andriej Kozyriew, pisząc „Naszym głównym zadaniem jest wciągniecie się, choćby za włosy, do klubu najbardziej rozwiniętych państw demokratycznych. Tylko w ten sposób Rosja odnajdzie niezbędną tożsamość narodową, a wraz z nią szacunek do samej siebie" ${ }^{\text {"10 }}$. Przyjęcie prozachoniego kursu w polityce zagranicznej Rosji na początku lat 90-tych wiązało się z koniecznością akceptacji upadku jej mocarstwowego charakteru. Nie było to łatwe zadanie, zwłaszcza, że Rosja w ciągu większej części swej historii była imperium i pretendowała do panowania w Europie i na świecie. Teraz musiała się pogodzić z tym, że traci uprzywilejowaną pozycję w systemie światowym, a niedawny wróg dyktuje jej nowe warunki egzystencji.

Niestety jakiekolwiek próby porównywania się z Zachodem na początku lat dziewięćdziesiątych przybierały dla Rosji niekorzystny obrót.

${ }^{8}$ Cyt. za: ibidem, s. 25.

9 Filozofia rosyjska wobec procesów modernizacyjnych, Kraków 1999, s. 171.

10 E. Wyciszkiewicz, Wspótczesna Rosja wobec Zachodu, Łódź 2003, s. 71. 
Stanisław Abramczyk w artykule pt. Rosyjska idea narodowa wskazuje na fakt, że po upadku bipolarnego systemu w kręgach samej dominującej rosyjskiej elity politycznej rozpowszechniło się wyobrażenie na temat Rosji jako kraju „niecywilizowanego”, w porównaniu z „cywilizowanym Zachodem”. „Ukształtował się swoisty kompleks westernizacji. Wzorce zagraniczne uważane są za formy neutralne kulturowo, które można bezboleśnie zapożyczać [...]. To co dzieje się w Rosji jest uzasadnionym wynikiem absurdalnego pomysłu stworzenia z niej «INNEGO» kraju oraz przyjęcia «mechanizmu doganiającego» Zachód"11.

Przez pierwsze lata transformacji dyplomacja rosyjska dążyła do utrzymania dwubiegunowości w stosunkach międzynarodowych. Podstawą rosyjskiej kalkulacji i oczekiwań na zachowanie pozycji równorzędnego partnera w stosunku do USA była Karta Amerykańsko-Rosyjskiego Partnerstwa i Przyjaźni, podpisana przez Georga Busha i Borysa Jelcyna na początku lat 90-tych. Rosja liczyła, że zmiany w kraju, takie jak deklaracja budowy demokracji i gospodarki rynkowej oraz przyjęcie zachodnich pryncypiów myślenia i postępowania przywrócąjej potencjał mocarstwowości. Świat w rosyjskiej koncepcji miał zachować dwubiegunowy charakter, z tą różnica, że oba jego człony miały być od tej pory sojusznikami - „Rosja i USA podzielają te same demokratyczne wartości. Ich interesy narodowe i państwowe nie znajdują się już w stanie konfliktu, ale w większości spraw międzynarodowych wzajemnie się uzupełniają [...]. USA i pozostałe demokracje zachodnie w taki sam naturalny sposób są przyjaciółmi i ewentualnymi sojusznikami demokratycznej Rosji, w jaki były wrogami totalitarnego ZSRR"12 powiedział Andriej Kozyriew. USA w rosyjskich analizach politycznych z lat 90. zajmują szczególne miejsce, traktowane są jako centrum decyzyjne Zachodu. Ta pozostałość zimnowojennego myślenia o stosunkach międzynarodowych, doprowadziła na początku zeszłej dekady, jak twierdzą liderzy JABŁOKA (Jawliński, Łukin, Bołdyriew) do zaniedbania realizacji strategicznych celów Rosji $\mathrm{w}$ imię nierealistycznej i niemożliwej kooperacji z Waszyngtonem ${ }^{13}$. Niezrealizowane pragnienie Rosji utrzymania dwubiegunowości, spowodowało pogorszenie stosunków na linii Rosja-USA. Rosyjski establishment oskarżał Waszyngton o ingerencję w wewnętrzne sprawy Rosji za pomocą

11 S. Abramczyk, Rosyjska idea Narodowa, „Dziś” 2000, nr 4.

12 B. Łomiński, Polityka Rosji wobec Europy zach., „Polityka Wschodnia” 1999, nr 2.

13 E. Wyciszkiewicz, Współczesna Rosja wobec Zachodu, Łódź 2003, s. 79. 
światowych instytucji finansowych, planowanie rozszerzenia NATO, dążenie do anulowania układu bilateralnego o obronie antyrakietowej ABM z 1972 roku oraz wykorzystywanie swej siły dla kształtowania jednobiegunowego systemu hegemonicznego.

Mimo wszystkich założeń, determinantów i strategicznych celów, rosyjska polityka względem USA z lat 90. jest bardzo niespójna. Obrazują to relacje między oboma państwami na płaszczyznach bezpieczeństwa i ekonomii.

Jednym z najważniejszych czynników organizujących rosyjską strategię obronną są stosunki Rosja-NATO. Sojusz Północnoatlantycki traktowany jest w Rosji jako zbrojne ramię USA, realizujące jego politykę bezpieczeństwa na świecie. Kiedy na początku 1993 r. NATO zaczęło rozważać kwestię rozszerzenia na wschód, Rosja przystąpiła do ofensywy dyplomatycznej i propagandowej przeciw temu projektowi. Jak pisze Kazimierz Malak z Akademii Obrony Narodowej w Warszawie, Rosja odrzuciła argumentację, w myśl której rozszerzenie Sojuszu jednoznaczne jest z powiększeniem strefy bezpieczeństwa w Europie, skupiając się na tym, jak rozszerzenie wpłynie na jej sytuację geopolityczną. W związku z tym ujawniła dwie nieprzychylne dla siebie konsekwencje. Po pierwsze rozszerzenie nie obejmuje Rosji, więc grozi jej izolacja polityczna i militarna, po drugie powiększenie NATO-wskiej strefy wpływów zmieni bilans sił na kontynencie, pogłębiając niekorzystne dla Rosji proporcje ${ }^{14}$. U schyłku 1996 roku Rosja zmieniła swe nastawienie w kluczowych kwestiach dotyczących relacji z NATO. Dialog z Sojuszem nabrał nowego charakteru mierzonego zacieśnieniem stosunków wzajemnych oraz zgodą Rosji na rozszerzenie NATO o państwa byłego bloku wschodniego. Ocieplenie wzajemnych kontaktów zaowocowało podpisaniem przez B. Jelcyna i B. Clintona 27 maja 1997 r. specjalnego porozumienia tzw. Karty NATO-Rosja (,Akt podstawowy o stosunkach dwustronnych współpracy i bezpieczeństwie między NATO i Federacją Rosyjską"). Dokument ten stał się krokiem do utrwalenia praktyki konsultacji polityczno- wojskowych NATO i Rosji służącej budowie wzajemnego zaufania. Wzajemne deklaracje nie wytrzymały jednak rozbieżności dzielących obie strony w sprawie interwencji NATO w Jugosławii w 1999 roku, które przyczyniły się do chwilowego zamrożenia stosunków.

14 Rosja między wspótczesnościq a historiq, pod red. A. Głowackiego, A. Stępień-Kuczyńskiej, Łódź 2002, s. 54. 
Atak na USA z 11 września 2001 r. zmienił determinanty rosyjskiej polityki względem Zachodu i NATO. Przystapienie Putina do koalicji antyterrorystycznej pozwoliło Rosji osiagnąć nowy statuts w relacjach z NATO. W maju 2002 roku w Rzymie powołano do życia nową Radę NATO-Rosja, w której - jak czytamy w komunikacie - państwa członkowskie NATO i Rosja będą współpracować jako równi partnerzy w dziedzinach wspólnego zainteresowania ${ }^{15}$. Rosja uzyskała w związku z tym nowe kompetencje: m.in. możliwość uczestnictwa w podejmowaniu decyzji (choć bez możliwości veta i decydowania o rozszerzeniu Sojuszu). Bliższa współpraca na polu militarnym odgrywa dla Rosji ważną rolę psychologiczną. Jest to dla niej znaczny krok w zapewnieniu sobie odpowiedniej pozycji na arenie międzynarodowej i pozbyciu się kompleksu „utraconej mocarstwowości”. Analizując majowe wydarzenia na konferencji prasowej tygodnika „Argumenty i Fakty” wiceprzewodnicząca Dumy Państwowej Irina Chakamada powiedziała: „Polityka rosyjska nareszcie odzyskała własną twarz. Po raz pierwszy zostały połączone strategiczne i taktyczne zadania, polityka zagraniczna zaś przestała być oderwana od polityki wewnętrznej. O dziwo - stawia przed sobą zadanie podwyższenia jakości życia ludzi i jednocześnie jest przesiąknięta chęcią przyłączenia się do klubu przodujących krajów"16.

Równie priorytetową dziedziną współpracy ze Stanami Zjednoczonymi jest dla Rosji sfera ekonomii. Lata 90. w Rosji to okres reform, liberalizacji gospodarki, ale też niestety walka z kolejnymi kryzysami. Rosyjskie elity polityczne zrozumiały, że bez pomocy zewnętrznej nie są w stanie odbudować i ustabilizować rosyjskiej gospodarki. Dlatego też zdaniem rosyjskich analityków, Rosja powinna unikać konfrontacji, szczególnie z Waszyngtonem, od którego zależy jej dalszy rozwój. Celem polityki rosyjskiej winno być zapewnienie sobie zagranicznych inwestycji i zacieśnienie współpracy handlowej, a nie nieustanna walka o odzyskanie utraconych pozycji. Na pierwszym miejscu w stosunkach z USA należy postawić uzyskanie korzyści ekonomicznych, a nie poszukiwanie nowych zagrożeń. Tak formułowana koncepcja polityki zagranicznej Rosji, łączona jest z pragmatyzmem, jaki rosyjskiej polityce zaczął nadawać Jewgienij Primakow (minister spraw zagranicznych od stycznia 1996). Primakow wyrażał przekonanie, że w stosunkach międzynarodowych następuje

15 Ibidem, s. 97.

16 Cytat z miesięcznika „Nowe Kontrasty”, czerwiec 2002. 
spadek znaczenia siły militarnej, kosztem wzrostu znaczenia czynników ekonomicznych. Następuje proces dyferencjacji świata i wyłanianie się biegunów - centrów siły i wpływów. W centrum znajduje się grupa najbardziej rozwiniętych państw - G7. Zasadniczym celem polityki Rosji powinno być znalezienie swojego miejsca w gospodarce światowej, wśród wysoko rozwiniętych państw ${ }^{17}$. Zasada ,wielobiegunowości” odpowiada rosyjskim interesom narodowym, zwłaszcza w sytuacji kiedy utrzymanie bipolarności stało się niemożliwe. Multipolarność przekłada się w rosyjskiej myśli na dążeniu do ograniczenia wpływów amerykańskich w świecie. W rosyjskiej strategii budowania świata wielobiegunowego priorytetowe znaczenie zyskuje zjednoczona Europa.

Pierwszym poważnym krokiem do zacieśnienia współpracy między Rosją a Unią Europejską w nowej „poradzieckiej” rzeczywistości politycznej był Układ o Partnerstwie i Współpracy podpisany 6 czerwca $1994 \mathrm{r}$. Dokument ten ustanowił legalne i instytucjonalne ramy dla współpracy, w których obie strony skierowały swoje wysiłki na wzmocnienie politycznych i gospodarczych więzi. Unia Europejska stanowi cel numer jeden rosyjskiej polityki zagranicznej, w stosunkach zaś dwustronnych najważniejszym europejskim partnerem są Niemcy. W realistycznym nurcie rosyjskiej myśli, Niemcy funkcjonują jako to państwo, które najlepiej rozumie znaczenie Rosji dla stabilności w Europie, a chcąc wypełnić swą historyczną misję musi „zakotwiczyć” Rosję w Europie. „Niemcy są centralnym punktem odniesienia rosyjskiej polityki zagranicznej. Czy to jako partner ekskluzywnego bilateralizmu, czy jako trampolina w drodze do Europy, czy jako potencjalne zagrożenie, otwierające możliwość alternatywnych sojuszy. Wszystkie te koncepcje mają jeden cel, jakim jest odwrócenie tendencji do marginalizacji Rosji i zapewnienie jej udziału we wszystkich sprawach europejskich"18 - pisze Łomiński w swoim artykule. Polityczne znaczenie stosunków rosyjsko-niemieckich, a także rosyjsko-francuskich wzrosło po 1997. Pojawiające się wówczas koncepcje rozszerzenia UE zmusiły Rosję do zastanowienia się nad swoją pozycją w nowo ukształtowanej przestrzeni europejskiej. Jedynym pragmatycznym rozwiązaniem stał się powrót do Europy. „Rosja winna przyjąć koncepcję «stawka na Europę», zamiast ubiegać się w latach 90. o strategiczne partnerstwo z USA, realizując tzw. «stawkę na Amerykę». Europa bardziej ro-

17 B. Łomiński, Polityka Rosji wobec Europy Zachodniej w latach 90., „Polityka Wschodnia" 1999, nr 2.

18 Ibidem. 
zumie Rosję niż USA, a Rosja ma więcej do zaoferowania Europie"19 twierdzili liberałowie skupieni wokół Jegora Gajdara (byłego premiera Rosji). Rok 1997 przyniósł tzw. „Wspólną Strategię” Rosji i UE, której celem było: umocnienie demokracji w Rosji, włączenie jej do wspólnej europejskiej przestrzeni gospodarczo-społecznej, współpraca dla umocnienia stabilizacji i bezpieczeństwa w Europie i poza nią. I. Schinger sekretarz stanu w niemieckim MSZ stwierdził, że „Rosja jest organiczną i niezbywalną częścią nowej Europy [...]. Bezpieczeństwo Europy możliwe jest do osiagnięcia wspólnie z Rosją, lecz nie przeciw niej"20.

Rozwój strategicznego partnerstwa FR i UE jest wyrazem współdziałania obu stron w kierunku osiągnięcia wspólnych celów. W interesie rosyjskich polityków leży wzmocnienie roli Rosji w Europie i świecie przez utworzenie paneuropejskiego systemu wspólnego bezpieczeństwa oraz zachęcenie UE do promowania rozwoju gospodarki rynkowej w Rosji i budowania w pełni demokratycznego państwa prawa. Odpowiednie mechanizmy współpracy pozwolą uniknąć Rosji marginalizacji i gospodarczej izolacji oraz zapobiegną powstawaniu nowych barier. W tej dziedzinie Moskwa dąży do kontynuowania pracy nad stworzeniem korzystnych warunków wejścia rosyjskich towarów na rynek europejski i wyeliminowania elementów dyskryminacji.

Ponadto priorytetem rosyjskiej polityki względem UE jest stworzenie podstaw głębokiej współpracy w dziedzinie finansowej. Kreml naciska na wzrost udzielanej pomocy technicznej poprzez unijne programy pomocowe, które chciałaby skierować na przyciagnięcie zagranicznych inwestycji do Rosji ${ }^{21}$.

Bardzo ważnym kierunkiem współpracy jest wdrażanie projektów inwestycyjnych w celu rozwoju dziedzin wydobycia ropy i gazu. Porozumienie z Paryża 2000 roku przyjęło zasadę „udziały za długi”, ustanawiającej pomoc finansową UE na budowę ropociągów, w zamian za udziały w zrealizowanym już projekcie.

Dopełnieniem bilateralnych kontaktów jest współpraca między rosyjskimi i unijnymi przedsiębiorstwami. Najważniejsze dziedziny współpracy to polepszenie klimatu inwestycyjnego w Rosji, kooperacja w sektorze energetycznym oraz technologii informatycznej, telekomunikacji i transporcie.

19 Ibidem.

20 M. Dobrosielski, UE a Rosja, „Dziś” 2000, nr 10.

21 A. Staszałek, UE i FR - wybrane zagadnienia, w: Rosja między współczesnościa a historia..., s. 78. 
Dyskusje toczone na forum dotyczą też poszerzenia udziału rosyjskich kół biznesu w unijnych projektach infrastrukturalnych i w wypracowaniu wspólnej polityki transportowej. Współpraca kół biznesu Rosji i Unii stanowi ważne uzupełnienie dialogu na szczeblu rządowym. Jest istotna ze względu na wage, jaką w rozmowach politycznych odgrywają kwestie gospodarcze.

Bogdan Łomiński w artykule Polityka Rosji wobec Europy Zachodniej w latach 90. wysuwa tezę, że hasło „Rosja w Europie” to problem znalezienia Rosji właściwego miejsca w nowej rzeczywistości politycznej. Dewiza ta nie oznacza jednak jednoznacznej jej interpretacji - Europa chce zneutralizowanej Rosji powiązanej z nią coraz gęstszą siecią współpracy, Rosja zaś problem ten postrzega jako konieczność uzyskania stosownego i odpowiadającego jej randze miejsca w Europie. Cytowany przez Łomińskiego B. Rychłowski za zasadniczą przyczynę niemożności instytucjonalnego włączenia Rosji w sprawy całej Europy uznaje „nieprzystawalność odmiennych tożsamości zbiorowych Rosji i Europy”22. Zdaniem autora, Rosjanie mimo iż chcą otrzymać miejsce w strukturach, to jednak nie zamierzają dostosowywać się do obowiązujących w nich zasad - „Chodzi o uzyskanie od Wspólnoty dokumentnego potwierdzenia, że Rosja to także Europa".

Lata 90. w Rosji pokazały jak trudno pozbyć się istniejących stereotypów i przyzwyczajeń mentalnych w formułowaniu determinantów polityki zagranicznej. Rosja powoli zastępuje „emocjonalne” podejście do Zachodu realizmem i pragmatyzmem. Zarówno w relacjach z USA, jak i UE gotowa jest na kompromisy i ustępstwa w imię realizacji strategicznych interesów.

Trzymając się tezy, że przyszłość Rosji uzależniona jest od pozycji, jaką zajmie ona względem Zachodu, trzeba dodać, że niewątpliwie największy wpływ na jakość i kierunek tej polityki ma prezydent FR. Objęcie urzędu prezydenta w Rosji przez Wladimira Putina, postaci enigmatycznej i zagadkowej, nasiliło pytania zagranicznych polityków o jego stosunek do Zachodu. Putin okazał się prezydentem podkreślającym konieczność strategicznego partnerstwa między Rosją a Zachodem. Zwraca uwagę na korzyści obu stron wynikające z poprawnych relacji. Dla Rosji kluczowe znaczenie mają zachodnie inwestycje w kraju oraz zacieśnienie współpracy handlowej, Zachód zaś potrzebuje silnej i stabilnej Rosji, gdyż tylko wtedy stanie się ona dla niego godnym zaufania i efektywnym partnerem

22 B. Łomiński, Polityka Rosji wobec Europy Zachodniej w latach 90., „Polityka Wschodnia" 1999, nr 2. 
gospodarczym i politycznym. Mając to na uwadze Putin w jednym z wywiadów zapewniał, że ,Rosja pod wieloma względami zmieniła zasady polityki zagranicznej. Już nie dąży do narzucania swojej woli komukolwiek [...]. Rosja będzie prowadzić politykę zagraniczną pozbawioną jakiegokolwiek wielkomocarstwowego szowinizmu. Jesteśmy nastawieni na rozwój równoprawnych stosunków ze wszystkimi krajami świata" ${ }^{\text {23 }}$. Putin konsekwentnie realizuje swoją wizję polityki zagranicznej, której podstawę stanowi pragmatyzm, efektywność gospodarcza, priorytet tzw. celów narodowych. Nawet najbardziej krytycznie nastawieni analitycy rosyjscy, zgadzają się, że za Putina Rosja ruszyła do przodu. Cytat z rosyjskiego tygodnika „Itogi” na temat Putina brzmi: „Putin jako lider narodu potrafił absolutnie precyzyjnie określić miejsce Rosji - nie tylko w słowach, ale i w czynach. Putin zdecydowanie przełożył zwrotnicę Rosji na Zachód”. Polskie zaś wydanie „Newsweek-a” tak przedstawia rosyjskiego prezydenta „Putin nie rozpacza nad końcem komunizmu. Żałuje utraconego przez kraj określonego miejsca na arenie międzynarodowej, ale rozumie, że Rosja musi obrać nowy kierunek zarówno w polityce wewnętrznej, jak i zagranicznej. Putin jest przekonany, że Rosja nie musi już dłużej obawiać się Zachodu"24.

Mimo tego wielu rosyjskich polityków oskarża prezydenta o niejednoznaczność i niezdecydowanie, co wyraża się w braku określonego programu politycznego. „Z jednej strony Putin znajduje wspólny język z liberałami i prozachodnim Związkiem Sił Prawicowych, utrzymuje świetne stosunki z przywódcami najważniejszych państw europejskich Gerhardem Schroederem i Tony Blairem. Program gospodarczy spotyka się z poparciem Międzynarodowego Funduszu Walutowego. Z drugiej Putina popierają antyzachodni poczwiennicy - euroazjaci z Aleksandrem Duginem na czele. Natomiast kontakty prezydenta z przywódcami Korei Pn., Iranu, Kuby, centralizacja władzy dają podstawy do oskarżeń o powracanie do praktyk sowieckich" - pisze o Putinie Wiaczesław Nikonow, prezes fundacji „Polityka”25. Putin zręcznie wykorzystuje retorykę charakterystyczną dla różnych ugrupowań politycznych, jednak dzięki temu wymyka się schematycznemu podziałowi rosyjskiej sceny politycznej na komunistów i liberałów.

Brak możliwości jednoznacznego zakwalifikowania prezydenta do neosłowianofilów czy okcydentalistów jest jego wyjątkowym atutem.

23 E. Wyciszkiewicz, Współczesna Rosja wobec Zachodu, Łódź 2003, s. 89.

24 Oba cytaty z „Nowych Kontrastów”, luty 2002.

25 Ibidem, s. 95. 
Oznacza to bowiem, że Putin nie podporządkowuje się teoretycznym założeniom jakieś ideologii, ale działania jego uwarunkowane są logiczną oceną sytuacji. Kończy z naiwnym biało-czarnym postrzeganiem stosunków z Zachodem opartych na schemacie miłość-nienawiść, nadając polityce zagranicznej Rosji nowy, niespotykany dotąd w historii wymiar. Rosja powoli pozbywa się tzw. „syndromu postimperialnego”, którego istotą jest brak realizmu w ocenie własnych możliwości na arenie międzynarodowej i w konsekwencji trudności w znalezieniu właściwej, odpowiadającej nowym realiom polityki zagranicznej. Przeciwnie, wreszcie dzięki polityce Putina, Rosja zajmuje precyzyjnie określone, prozachodnie stanowisko. „Sojusz z Zachodem jest potrzebny Rosji jak powietrze. Kiedy określimy się nareszcie jako kraj zachodni, uznamy za fakt, że jesteśmy zachodni, ze względu na nasze instytucje, na wyznawane wartości, kulturę europejską - dopiero wówczas odpowiemy na przeklęte rosyjskie pytanie, które od 300 lat rozdziera samoświadomość narodową - KIM JESTEŚMY?” pisze dziennikarz „Itogi”

Okres konfrontacji na linii Rosja-Zachód dobiega końca. Uwidaczniający się w polityce zagranicznej stosunek Rosji do państw zachodnich pozwala wysunąć tezę o stopniowym zanikaniu w Rosji radykalnie antyokcydentalistycznych nastrojów. Rosja przestała budować swoje relacje ze światem zachodnim na kruchych ideologicznych fundamentach, zastępując je takimi wyznacznikami jak interes narodowy czy wyższa konieczność.

Wygląda więc na to, że na pytanie „Dokąd zmierzasz Rosjo?”, jeszcze długo będzie nam odpowiadać - NA ZACHÓD.

\section{Summary}

The West has been one of the most significant reference criteria for the Russian political, historical or ideological thought. The reason for this is that Russian identity has been shaped mainly by virtue of comparison to the West. Therefore, Russian self-reflection is always assessed by means of Russian relation to the West. This relation has assumed various dimensions in different times, yet it has always ranged from utter admiration for the Western civilization to extreme disapproval of its achievements. At present Russia no longer develops her relations with the West on the fragile foundations of ideology that has been substituted by the factors of national interest or higher necessity. Therefore it seems that when asked "Where are you heading, Russia?" she is going to keep answering „Westwards" for a long time to come. 